\title{
百日咳菌のマウス腹腔内感染の病因について
}

\section{1. 腹腔內の菌の消長己食菌作用との関係}

\author{
沢井芳男下条寬人 \\ 東京大学伝染病研究所試験製造室（主任 沢井芳男助教授）
}

[受付 : 11 月 11 日・1958 年]

\section{まえがき}

百日晐菌をウサギ，モルモツト，あるいはマウスの腹 腔内に接種して動物劣死に至らしめるには，他の接種経 路，たとえば脳内接種; あるいは終鼻接種よりもはるか に大量の菌を必要としている ${ }^{12)}$ 。したがつて腹腔内接 種による百日咳菌感染の病因は，菌がその中で増殖した 結果というょりもさしろ菌の毒素にょる中毒死と見るべ きであると考えられてきた。

しかし一方では毒素が菌の感染に重要な役割を演じて いることを示唆している報告3) もり，あるいは何故腹 腔内接種は他の経路よりも大量の菌を必要とするのかと いう疑問も残されているので，てれ等の問題を分析し， 腹腔内感染の機序を明らかにするために，マウスを用 い, 腹腔内に接種された菌の運命を特に食細胞この関連 に㧍いて追求した結果, 2,3 の新知見を得たのでことに 報告して大方の御批判をあ拉ぐ次第である。

\section{実験材料と実験方法}

使用菌株は東浜株, 大塚株, 中村株 1 相菌, 及び東浜 株, 坂入株 III相菌をボルデー, ジヤング (B・G) 培地 に $37^{\circ} \mathrm{C} 48$ 時間培養したものを用いた。菌浮遊液には生理 食塩水を用い, 光電比色計を用いて予め作製した標準曲 線と照し合せ乍ら所定の菌濃度に調製した。マウスは伝 研で飼育された ddF 系を用いた。

上記の一定量の菌定マウスの腹腔に接種し, 一定時間 毎にガラスの毛細管で腹腔液を 採取し, 塗抹榗本を作 り, ギムザ染色を行つた後に検鏡し, 白血球の食菌と細 胞外の菌の消長を追及した。白血球は 100 個を数え, 多 核白血球の食菌していないもの，1 個〜 5 個， 6 個〜10 個, 10 個以上食菌しているものをわけて記録し,グラフ を作り食菌の推移を明ら办にした, 一部は単核白血球に ついても同様な検查を行つた。

\section{実験成績}

実験 1 , 東浜株, 大塚株 1 相菌, 及び坂入株 III相菌の 32bil.( 320 億) 及び 8 bil. ずつを $0.5 \mathrm{ml}$ の生理食塩水 に浮遊し, 生後 4 週の d dE 系マウス 5 匹ずつの腹腔に 注射し, 時間を追つて腹腔液の検查を行つた。その結果 は第 1 表にまとめられているが，腹胿局所の経過恃第 1 図に示されたような 3 つ型に大別された。そのひとつ は東浜 1 相菌, 32bil. 接種群, マウス No. 1 にみられ たもので，接種後 5 時間の標本では大部分の多核白血球 は最大限の食菌を行つて扢り, 細胞外の菌は極度に減少 して 1 視野に10〜20個程度であつた。そして更に時間が 進及, 24 時間前後のものでは多核白血球の食菌は峠を越 し，食菌を行わない白血球の数が増加するにも拘らず細 胞外に少数の菌が動物无死に至るまで食菌されずに残さ れている。そこで動物の死は, 細胞外にわずかに残存し ている菌によるというよりも, むしろ I 相菌の毒素の障 害作用によると見るべきであると考え, この様な経過を とるものを非敗血症型 (non-sepsis form) と名付けた (写真 2 )。すなわち白血球の菌を清掃する力が大であ ることを意味している。

これに反して上と同様に 32bil. 接種群の No. 2 のマ ウスは接種された菌がそのまま㴗とんど減少する様子が なく経過し, 白血球数は前者の例にくらべると著しく少 く, また最大限に食菌した白血球の周囲には多数の菌の. 吸着がみとめられ, 多くの場合核が変性し, 崩壊してい る像も多数認められている。この様にして細胞が崩壊し

SAWAI Yosio and SHIMOJO Hiroto: Studies on the pathogenesis of intraperitoneal infection of $\mathrm{H}$. pertussis in mice 1. Relationship between the clearance of bacilli from peritoneal cavity and phagocytosis. Laboratory of Biological Products, Institute for Infectious Diseases, the Univ of Tokyo.-Jap. J. of Bact., 419-424, 1959. 
第 1 妻

\begin{tabular}{|c|c|c|c|c|c|c|c|c|}
\hline 菌 & & 株 & 接種 菌量 & マウス生/使用数 & 敗 血 症型 & 非敗血症型 & 回 & 復 型 \\
\hline & \multirow{2}{*}{ 浜 } & \multirow{2}{*}{ I } & 32 bil & $.0 / 5$ & 3 & 2 & & 0 \\
\hline & & & 8 bil & $3 / 5$ & 0 & 2 & & 3 \\
\hline & \multirow{2}{*}{ 塚 } & \multirow{2}{*}{ I } & 32 bil & $1 / 5$ & 2 & 2 & & 1 \\
\hline & & & 8 bil & $4 / 5$ & 0 & 1 & & 4 \\
\hline \multirow{2}{*}{ 坂 } & \multirow{2}{*}{ 入 } & \multirow{2}{*}{ III 相 } & 32 bil & $5 / 5$ & 0 & 0 & & 5 \\
\hline & & & 8 bil & $5 / 5$ & 0 & 0 & & 5 \\
\hline
\end{tabular}

第 1 図 各感染型における金菌像の推移

東浜 I 相 32 bil（マウス No. 1) 非敗血症型
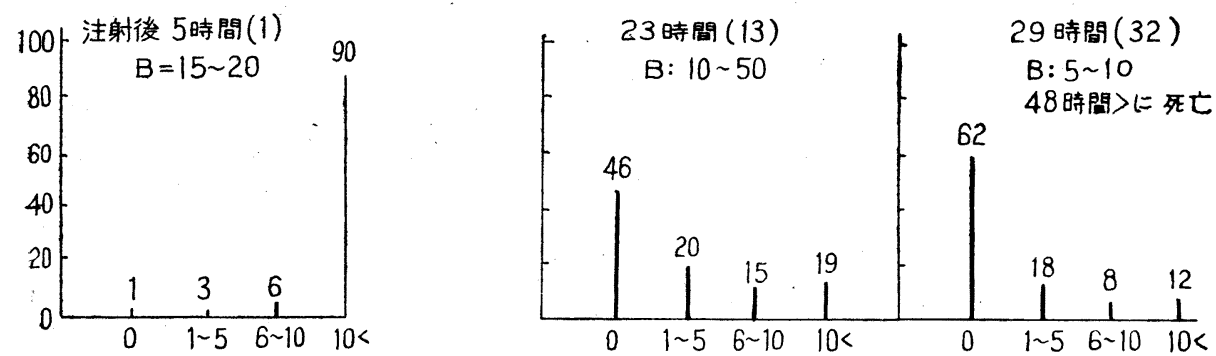

東浜 I 相 32 bil（マウス No. 2) 敗血症型

5 時間 (3)

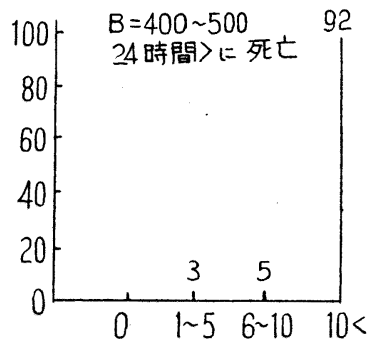

東浜 I 相 8 bil（マウス No. 6）回復型
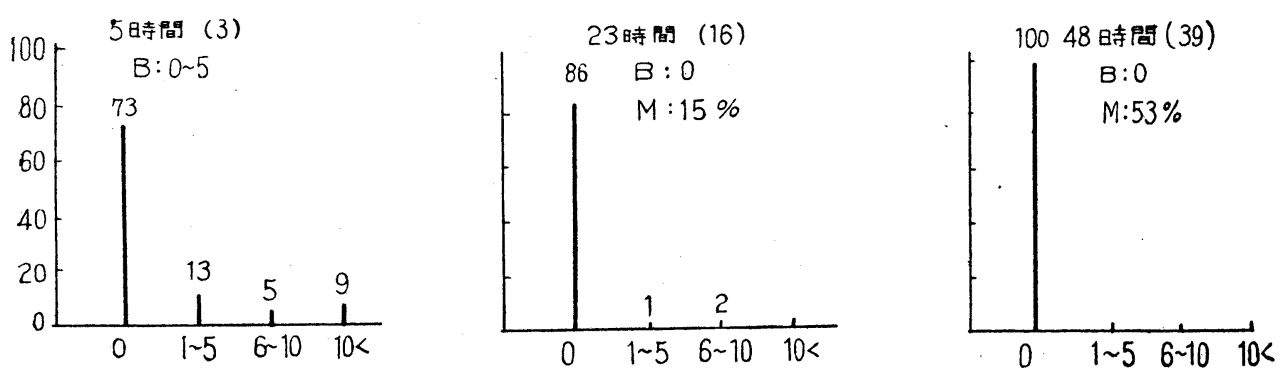

註 : グラフのよて軸 $\mathrm{O}$ ：食菌していない血球，1〜5: 1 個から 5 個食菌している白血球，以下 同じえて軸はそれぞれの区分けした白血球数を表す。B： 細胞外の䇢数 ( 1 視野中), カッコ 内は標本番号。M は視野中の単核白血球 
食菌が妨げられる為に腹腔内の菌はむしろ増殖の㑯向さ えみられ，前の 感染例とは 全く異つた経過をたざるの で，乙の溙なマウス群を敗血症型 (Sepsis form) と名 ずけた（写真 1 ), これらの動物はすべて48時間以内に死 亡した。

第 3 の型怯東浜 I 相菌， 8 bil. マウス No. 6，あるい は正相菌感染に見られたように，マウスはすべて生き残 る。菌は最初の 5 時間の整本で殆んぞ細胞外に見えな くなり, 多核白血球による食菌も僅少で既に峠を越して いた，24時間後の標本では細胞外の菌は全くなくなり， 細胞内の菌も極くわずかに見られる程度であつた。この 時期には単核細胞か $15 \%$ 内外に出現して回復の兆候示 し、48時間後では50\%あるいはそれ以上にも梨つた。こ のような経過に対して回復型（recovery form）と名ず けた。

実駼2，菌株は前之同様に東浜株 I 相菌学用い，マウ スは $\mathrm{ddF}$ 系, 生後 4 週のものを用いた。菌の32bil, 16 bil， 8 bil. 4 bil。をそれぞれ 3 匹ずつのマウスの腹腔に 注射し，12．15．18．24．36．39時間に腹腔液の塗抹祭 本を作り前と同様の検査を行つた。

第 2 表

\begin{tabular}{c|c|c|c}
\hline 菌 量 & マスウ生/使用数 & 敗血症型 & 非敗血症型 \\
\hline $32 \mathrm{bil}$ & $0 / 3$ & 2 & 1 \\
$16 \mathrm{bil}$ & $0 / 3$ & 3 & 0 \\
$8 \mathrm{bil}$ & $0 / 3$ & 1 & 2 \\
$4 \mathrm{bil}$ & $0 / 2$ & 1 & 1 \\
\hline
\end{tabular}

実験成績泣表 2 に示された通りであるがこれ等の接種 マウスの中で敗血症型をたどつたすのは前と同様に渗出 白血球数が少く, 且つ残つた白血球は最大限に食菌して いながら崩壊する像が著明で, 細胞外の菌は殆んご減少 せず, 白血球の周囲にも濃厚に密着している為に塗抹標 本ではあたかも崩壊した細胞方ら菌が遊出しているかの 様な観を呈するものさえみられた。

これに反して非敗血症型のものでは接種後12時間では 細胞外の菌は少数で, 食菌作用も漸次減退するが, 白血 球数は非常に多く，敗血症型のような崩壊像は全く認め られなかつた。マ!スの死亡直前の樭本では単核白血球 が10〜20\%にも出現していた。この様な像も敗血症型に は見られなかつた。

実験 3 本実験では極く早期における菌の消長字しら べる目的で ddF 系マウス 5 匹に大塚株 I 相菌 10bil. を 腹腔に注射し, 15 分， 30 分 1 時間， 2 時間， 3 時間， 6

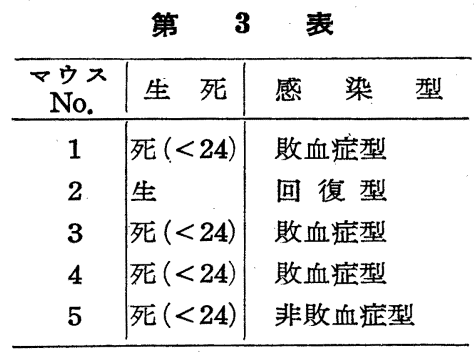

註 : カッュ内 $<24$ は 24 時間以内 飞死亡したこをを示す, dd 4 週, 大塚株 I 相菌, 10 bil. 注射。

時間及び 24 時間の腹胿液の眐本について検査を行つた。 実験成績恃第 3 表になとめているが，5匹中 3 匹が敗血 症型， 1 匹が非敗血症型，残りの 1 匹が回復型を 示し た，また第 2 罒に示されたように，多核白血球の渗出は 注射後 30 分あるいは 60 分に既に増加の傾向がみられた が，著明な増加は 2 時間または 3 時間後であつた。細胞 外の菌の消長注注射後15分では 1 視野に 100〜 200個を 数え，敗血症及び非敗血症による差は認められなかつた が，明らかなのは敗血症型の経過をとつたものでは，乙 の時期にも渗出前に局所に遊走している少数の多核白血 球にすでに崩壊があられていた。これに反して回復型の 場合には驚くべきととはこの時期に既に細胞外の菌は殆 んど全く無菌となつて抢り，わずかに遊走している単核 あるいは多核白血球の中にごく少数の菌が食菌されてい るに過きなかつた。

非敗血症型では 30 分頃から細胞外の菌が減少する傾向 がみられたが著明な白血球の増加は３時間後であつた。

\section{考竅}

との等の実験成績から，マウスの腹腔内に同じ菌量を 接種した場合にも，3つの異つた感染経過をとることが わかつた。この相違怡第1 亿腹肤内の菌の清掃 (clearance）に著しい差がみられることである。第 2 はとく に多核白血球にみられる阻害作用である。敗血症型と名 付けたのは白血球があたかもグラム陽性球菌にみられる ロイコジン (leucocidin) 様1)5)の作用をうけた結果, 菌 の清掃が妨げられ，そのために菌の増殖が起るものと考 えられたからであつて，局所のみならず全身的にも，て の様な増殖がみられるかでうかは別の問題として局所て は少くとも菌の增殖を思わせるような像がみられたから である。従つて敗血症型の特徴は白血球の崩壊 (lysis), 従つて白血球数の 減少 (leucopenia) が著明で, 菌の清 
掃が極度に阻害される。従つて動物の死因はもちろん毒 素が大きな役割を演じているとはいえ，や怡り菌增殖と いう因子もこれに加わつているものと考えられる。崩 夜していく白血球は毎常最大限に食菌しているが, 核が ピクノーゼを起し, 細胞膜は 破壊されていることが多 い,また非敗血症型の場合と異つて白血球の周囲に菌 が吸着して密集しているのが特徵であつて, あたかも 細胞内の菌があふれ出したのではないかとさえ考えられ る。また白血球が菌によつて攻撃されている樣な感じ さえうける。非敗血症の場合に柱菌数が多く若干菌が吸 着している様な像もみられるが, 白血球数はあまり減少 せず，崩壊像も著しくない，また時期が進めば白血球の 增加が著明で, 菌の堿少も目立つてくる。この場合の特
徵は極め少数であるが細胞外に菌が食菌されずに残さ れることである。この点回復型で早期に菌が消隇するの とは異る。この場合多核白血球の增加も著明で, 食菌を していないものも多数見られるにも拘らず, 少数の細胞 外の菌をとり込む事が出来ないのは一見奇異な感じであ る。

この時期の菌にある種の抵抗性があらわれたのか, あ るいは白血球の機能が衰えた為であるかは不明である。 この点毒素が菌の侵襲性 (invasiveness) を助けている という考え方が出てくるかも知れない ${ }^{6)}$ 。またこの様に 若干の菌が残存する為に, 回復型の時の様に早期に多数 の単核細胞の渗出がみられず，多核白血球が依然死に至 るまで優勢を続けている点にも興味がある。何れにして
15 分

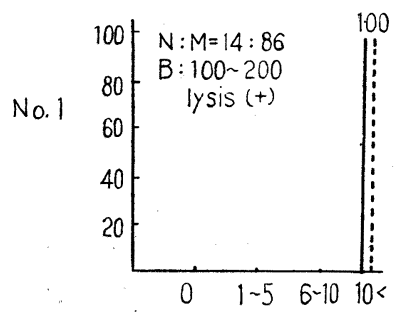

15 分

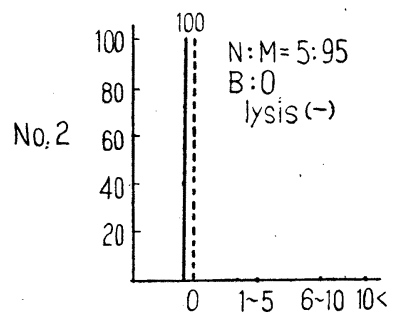

15 分

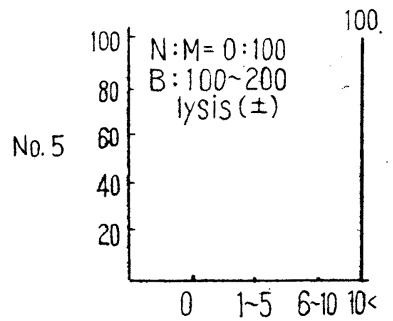

$\underline{30 \text { 分 }}$

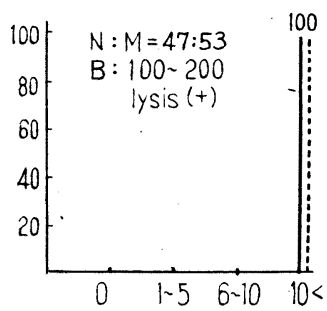

$\underline{30 \text { 分 }}$

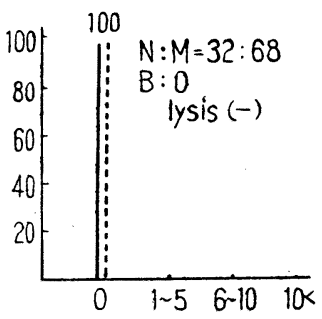

30 分

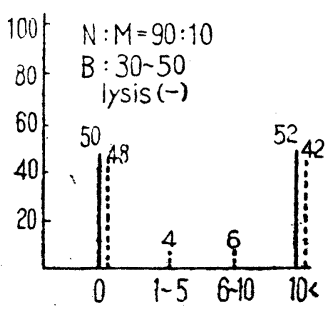

第

2

60 分

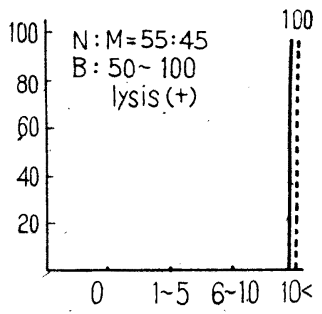

$\underline{60 \text { 分 }}$

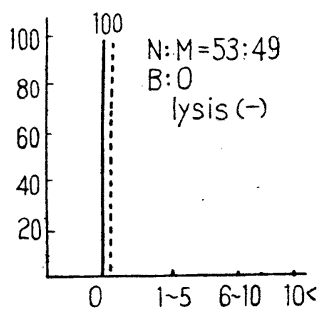

$\underline{60}$ 牢

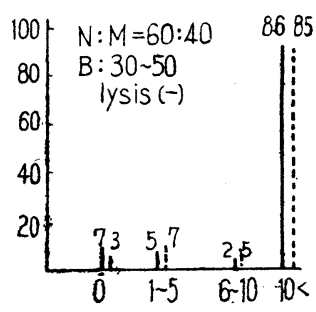

註 : 困中点線は多核白血球, 実線は単核白血球数を示す, 
写真 1 百日咳菌 I 相菌 (東浜株) 4 bil を腹腫内 注射後 15 時間, 腹腔液ギムザ染色. (敗血症型)

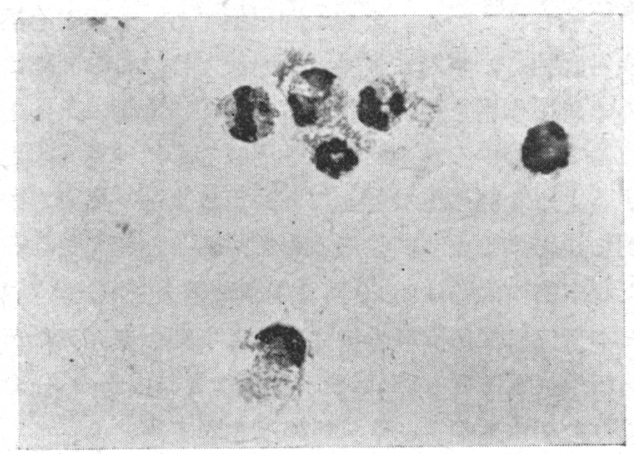

図
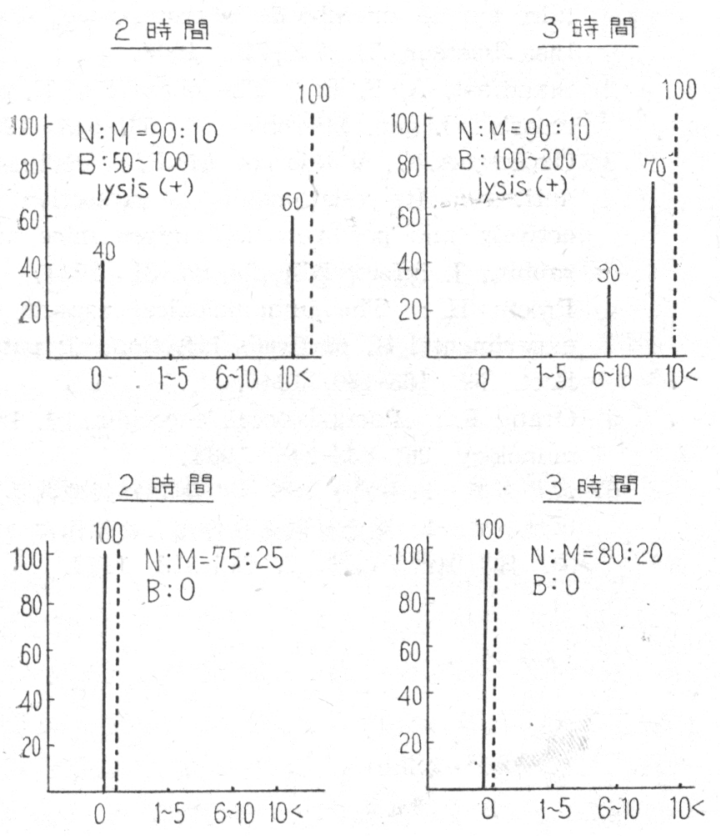

2 時間

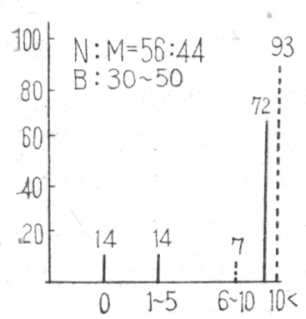

$\mathrm{N}$ : M は多核白血球と単核白血球との比

3 時閣

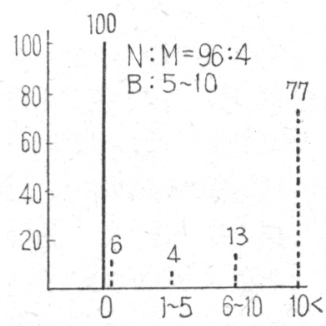

写真 2 同上 8 bil 注射, 12 時間後. (非敗血症型)

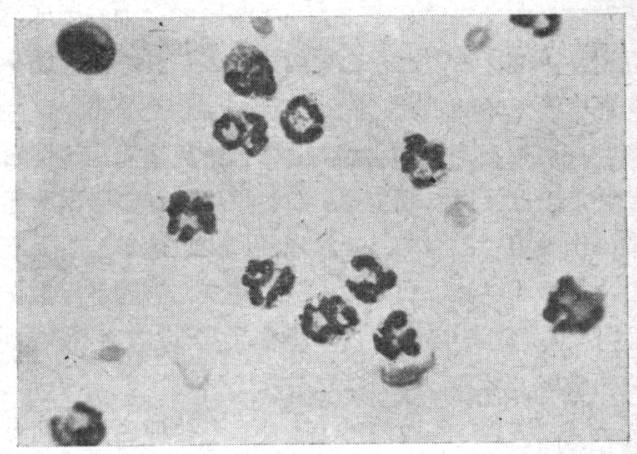

6 時間
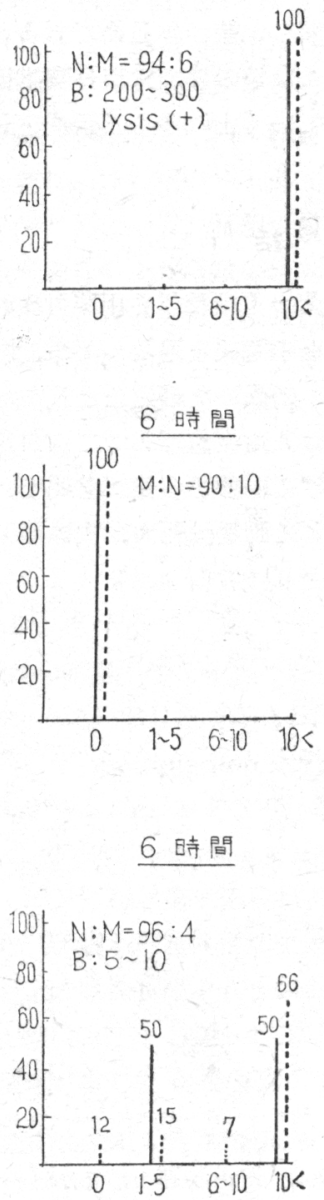
もこの様な感染様式は対照に用いた相菌には見られな かつた。これに反して回復型, あるいは政相菌感染では 菌の清掃能率愫睛しく, ふつろ数時間で細胞内外の菌 は局所加消える。ことに実験 3 亿女られた例は 15 分と いうわずかな時間内に，同時に注射された他のマウスで は腹腔液は未だ菌の洪水であるのに, 見事完全に清掃さ れているのは注目に価する。てれは血球の渗出が起る 以前の出来事であつて, それ以前に少数遊走している局 所の白血球だけによつてての様な完全な清掃が行われた 己は考えられないので，乙の場合はでうしても液性の強 い殺菌機構が考えられねばならないっ。

従来百日咳菌の腹胿内感染怯むしろ接種された菌から 分泌される毒素による中毒死であるという見方をされて きた。従つて敗血症型の場合にも菌の清掃の障害がどの 程度の役割を演じているかは明らかではないが, 腹胿内 での菌の清掃, あるいは白血球に対する障害に著明な差 のあることば，生体反応に著しい差がある為であると見 なければならない。従つててれ等の事実は百日咳感染あ るいは免疫の機序を分析していく上に多くの示唆を与え るものと考えられる。

\section{総 括}

マウスの腹腔内に百日咳菌の I 相及び杰相菌を注射し て腹胿内の菌の清掃と食菌との関係を追及したが, 同じ 菌量を接種した場合でも 3 つ異つた経過をとるここが 明らかにされた。その1つは敗血症型であつて白血球が ロイコシデン様の作用を受けて崩壊する像が著明で, 菌 はさしろ増殖する傾向を示して動物㹥死ぬ, 次は非敗血
症型で, 白血球の崩壊は全く起らず, 菌の清掃も時間と 共に進むが死に至るまで極く少数の菌が食菌されずに細 胞外に残されている。第 3 は回復型であつて菌の清掃力 は異常に強く, 早期に腹胿方ら消隇する。との機作怯細 胞外の殺菌作用を想定させる。との㮏に菌側の条件を同 一にしていわゆる純系マウスを用いても，一見病因を異 にするような経過をたどるととは百晐菌の感染の機作 を明らかにする上に興味ある事実であると考えられる。

な打本稿の大要は第 29 回日本細菌学会で演述された， また本研究は文部省科学研究費による綜合研究班細菌性 小児伝染病予防研究班 (班長 野辺地慶三博士の)一環 と して行われたもので, こてと謝意を表する。

\section{文 献}

1) Bordet, J. \& Gengou, O. : Note complémentaire sur le microbe de la coqueluche., Ann. Inst. Pasteur, 21, 720-726, 1907.

2) Standfast, A. F. B. : The phase I of H. pertussis., J. gen. Microbiol., 5, 531-545, 1951.

3) Ospeck, A. G. \& Roberts, M. E. : Pertussis antitoxin, Its relationship to protection in actively and passively immunized mice and rabbit., J. infect. Dis., 74, 22-31, 1944.

4) Proom, H.: The immunological aspects of experimental $\mathrm{H}$. pertussis infection., J. path. Bact., 59, 165-180, 1947.

5) Oram, F. : Pneumococcal leucocidin., J. Immunology, 26, 233-246, 1934.

6）沢井芳男, 田中光: マウスの弱毒肺炎球菌感染 につ、て，1. 感染経過と食作用との関係につい $\tau$, 日本細菌学雑誌, $7,515-518,1952$. 